\title{
Frequency Distribution of Hemoglobin Variants and Rhesus Blood Groups Among Pregnant Women
}

\author{
${ }^{1}$ Oyeyemi Ifeoluwa Temitayo and ${ }^{2}$ Salawu Oyetunde Timothy \\ ${ }^{1}$ Department of Zoology, Faculty of Science, University of Ibadan, Ibadan, Nigeria \\ ${ }^{2}$ Department of Biosciences and Biotechnology, \\ School of Basic and Applied Sciences, Babcock University, Ilishan-Remo, Nigeria
}

Received 2012-08-21, Revised 2012-09-25; Accepted 2013-04-18

\begin{abstract}
Hemoglobin variants, $\mathrm{ABO}$ and Rhesus blood groups vary from one population to another. The study was designed to sample pregnant women population from Ayetoro community of Ogun state, Nigeria, for the purpose of updating information on the prevalence of abnormal hemoglobin variants, $\mathrm{ABO}$ and $\mathrm{Rh}$ blood groups and compare the results with previously published data. Hospital records of recruited pregnant women were sorted out for the determination of the prevalence of hemoglobin variants, $\mathrm{ABO}$ and $\mathrm{Rh}$ blood groups. Blood group O were the most prevalent (59.1\%) followed by groups A (19.1\%), B (17.1\%) and AB (4.8\%). Rhesus D antigen was positive in $97.1 \%$ and negative in $2.9 \%$ of the study population. Four genotypes; HbAA (70.5\%), HbAS (18.1\%), $\mathrm{HbAC}(10.5 \%)$ and $\mathrm{HbCC}(1.0 \%)$ were reported in this study. The occurrence of the hemoglobin variants and the different $\mathrm{ABO}$ blood groups varied significantly $(\mathrm{p}<0.05)$. The frequency of $\mathrm{ABO}$ and Rhesus blood groups from this study is consistent with reports from previous studies in Nigeria. The study helps in the formulation of genetic counseling policies to help prospective mothers make informed decisions before and after giving birth.
\end{abstract}

Keywords: Pregnant Women, Hemoglobin Genotypes, ABO Blood Groups, Rhesus

\section{INTRODUCTION}

The $\mathrm{ABO}$ and $\mathrm{Rh}$ blood groups are among the most important blood groups (Seeley et al., 2008). ABO blood groups are carbohydrate histo-blood antigens that are also expressed in many tissues and which have important roles in modulating protein activities both in infection and in some types of cancer (Greenwell, 1997). These antigens are formed by terminal glycosylation of glycoproteins and glycolipid chains present on cell surfaces.

Cell surface glycans have an essential role in reproductive biology and the adhesion and implantation of the blastocyst is partly mediated by carbohydrates with blood group specificity (Burrows et al., 1994). Each mammalian species has its own glycotype at the fetomaternal interface and this variation depends on both evolution and the environment (Jones et al., 2004). ABO histo-blood groups and related antigens are expressed in the endometrium and are modulated by the hormonal environment (Skovlund, 1997), but are not expressed in the placenta and fetal endothelium where only other related blood groups can be detected in the interstitial trophoblast directly opposed to the maternal deciduas (Ravn and Dabelsteen, 2000). In contrast, examination of the glycan expression at the fetomaternal interface using lectins, some with $\mathrm{ABO}$ determinant specificity have shown binding with placental structures (Thrower et al., 1990; Jones et al., 1997).

Rhesus system emerged as second most important blood group system due to Hemolytic Disease of Newborn (HDN) and its importance in Rh D negative individuals in subsequent transfusions once they develop $\mathrm{Rh}$ antibodies (Dennis et al., 1998). People are positive if they have a certain $\mathrm{Rh}$ antigen (the $\mathrm{D}$ antigen) on the surface of their erythrocytes and people are Rh-negative if they do not have Corresponding Author: Salawu Oyetunde Timothy, Department of Zoology, Faculty of Science, University of Ibadan, Ibadan, Nigeria 
this Rh antigen. Rhesus incompatibility can pose a major problem in some pregnancies when the mother is Rhnegative and the fetus is Rh-positive (Avent, 1998) where it can lead to HDN, or erythroblastosis foetalis and it may be fatal to the fetus (Dennis et al., 1998).

Sickle cell Hemoglobin ( $\mathrm{HbS}$ ) differs from normal Hemoglobin (HbA) because it has a valine in place of a glutamic acid in position number six of the beta chain of the globin molecule. When the availability of oxygen is reduced, the erythrocytes containing sickle cell hemoglobin change from round to sickle-shaped cells. The sickle cell Homozygote (HbSHbS) almost always dies of anemia. The sickle cell Heterozygote (HbAHbS) is only slightly anemic and has resistance to malaria (Tamarin, 2002). The normal Homozygote (HbAHbA) is not anemic and has no resistance to malaria. Thus, in areas where malaria is common, the fit genotype of the three appears to be the sickle cell heterozygote, which has resistance to malaria and only a minor anemia.

This study presents the frequency distribution of $\mathrm{ABO}$ and $\mathrm{Rh}$ blood groups and the frequency distribution of blood genotypes in this pregnant women population.

\section{MATERIALS AND METHODS}

The study was conducted in Ayetoro, the head quarter of Yewa North Local Government Area, Ogun State. It is a peri-urban community with three secondary schools and numerous private and government owned primary schools. The predominant occupations are civil service, farming and petty trading. The community has three primary health centers with one government owned hospital (General Hospital, Ayetoro). It is a heterogeneous community comprising people of different ethnic groups such as Yorubas, Fulanis, Ogoris and people from the Republic of Benin.

The medical records of a total of 105 pregnant women attending antenatal consultation at the Ayetoro General Hospital between July, 2011 and January, 2012 were retrieved having obtained an oral informed consent from the subjects. Only the pregnant women willing to participate in the study and those that have resided in the area for at least a period of one year were recruited while visitors were excluded from the study. Information on each pregnant woman blood group and hemoglobin genotype was recorded against their name.

\subsection{Statistical Analysis}

Data was analyzed using computer database software from the Statistical Package for Social Sciences (version 17; SPSS Inc., Chicago, IL). Frequency distribution and prevalence of the various parameters were determined. Differences in proportions were determined by chi- square tests. A P-value of $<0.05$ was considered statistically significant in all clinical comparisons.

\section{RESULTS}

The overall frequencies of the $\mathrm{ABO}$ and $\mathrm{Rh}$ blood groups in the pregnant women population $(n=105)$ are shown on Table 1. The most and the least prevalent blood groups were blood group $\mathrm{O}$ and $\mathrm{AB}$ with 59.1 and $4.8 \%$ respectively. Rhesus $\mathrm{D}^{+}$and $\mathrm{Rh}^{-}$accounted for 97.1 and $2.9 \%$ respectively. The frequencies of $\mathrm{Rh} \mathrm{D}$ groups among the four ABO groups are shown in Table 2. No $\mathrm{Rh} \mathrm{D}^{-}$was recorded in the blood groups $\mathrm{A}$ and $\mathrm{AB}$. The most predominant hemoglobin genotype was $\mathrm{HbAA}$ (70.5\%) (Table 3). The hemoglobin variants $\mathrm{HbSC}$ and $\mathrm{HbCC}$ did not occur in this study population. There were significant differences in the occurrence of $\mathrm{ABO}$ blood groups and hemoglobin genotypes in the pregnant women population $(\mathrm{p}<0.05)$.

Table 1. Frequencies of $\mathrm{ABO} \mathrm{Rh}$ blood groups among pregnant women participants $(n=105)$

\begin{tabular}{lrrr}
\hline Variables & & Number observed & Prevalence (\%) \\
\hline Blood groups & & & \\
& $\mathrm{A}$ & 20 & 19.10 \\
& $\mathrm{~B}$ & 18 & 17.10 \\
& $\mathrm{AB}$ & 5 & 4.80 \\
& $\mathrm{O}$ & 62 & 59.10 \\
Rhesus (Rh) & & $\mathrm{p}<0.05$ \\
& $\mathrm{D}^{+}$ & 102 & \\
& $\mathrm{D}^{-}$ & 3 & 97.10 \\
& & & $\mathrm{p}<0.05$ \\
\hline
\end{tabular}

Table 2. Rhesus ( $\mathrm{Rh}$ ) D distribution among pregnant women in ABO blood groups

\begin{tabular}{lcc}
\hline Blood group & Rh D Positive (\%) & Rh D Negative (\%) \\
\hline A & $20(19.1)$ & - \\
B & $17(16.2)$ & $1(1.0)$ \\
AB & $5(4.8)$ & - \\
O & $60(57.1)$ & $2(1.9)$ \\
Total & $102(97.1)$ & $3(2.9)$ \\
\hline
\end{tabular}

Table 3. Frequencies of hemoglobin genotypes among pregnant women

\begin{tabular}{lrr}
\hline Hb genotypes & Number observed & Prevalence $(\%)$ \\
\hline AA & 74 & 70.50 \\
AS & 19 & 18.10 \\
AC & 11 & 10.50 \\
CC & 1 & 1.00 \\
SS & 0 & 0.00 \\
SC & 0 & 0.00 \\
& & $\mathrm{p}<0.05$ \\
Total & 105 & 100.00 \\
\hline
\end{tabular}




\section{DISCUSSION}

This study was designed to evaluate the frequency of the most clinically relevant and routinely tested blood groups and hemoglobin genotypes in pregnant women population in South- western Nigeria. The prevalence of ABO blood groups reported in our study is similar to other studies from other part of the country (Jeremiah, 2005; Bakare et al., 2006; Uneke et al., 2007; Erhabor et al., 2010). A frequency of $26.7 \%$ for group A, $18.3 \%$ for B, $2.2 \%$ for $\mathrm{AB}$ and $52.8 \%$ for group $\mathrm{O}$ from the Southsouthern Nigeria was reported by Jeremiah (2005) while Uneke et al. (2007) from South-eastern Nigeria reported a frequency of $25.0 \%$ for group A, $16.4 \%$ for B, $1.9 \%$ for $\mathrm{AB}$ and $56.7 \%$ for group $\mathrm{O}$. These all showed a consistent highest frequency of group $\mathrm{O}$ individuals with group $\mathrm{AB}$ having the least frequency in their respective study population.

The high prevalence of group $\mathrm{O}$ individuals in nature is of great advantage because of their status as 'universal donors' as this implies availability of blood in cases of emergency. However, caution should be taken in doing this as some group $\mathrm{O}$ blood is known to contain potent immune hemolytic antibodies (hemolysins) (Jeremiah, 2006). Routine hemolysin test on every group O blood will help reduce the risk of transfusion reaction. More so, the $\mathrm{O}$ phenotype has been reported to show parity-specific association with protective malaria immunity in pregnancy leading to improved birth anthropometry (Loscertales and Brabin, 2006).

The frequency of $\mathrm{Rh} \mathrm{D}$ positive was $97.1 \%$ while that of $\mathrm{Rh} \mathrm{D}$ negative was $2.9 \%$. This is in consonance with other reports on Nigerian pregnant women and students' populations (Jeremiah and Buseri, 2003; Jeremiah, 2005; Akigbe et al., 2009). The 2.9\% Rh D negative women in this study stand the risk of developing anti-D which can cause both moderate and severe form of hemolytic disease of the newborn. However inclusion of this test in antenatal programs especially for the primigravid mothers, followed by appropriate health education will reduce the risk of the disease.

Previous studies from Nigeria have reported the presence of 2-6 hemoglobin genotypes (Jeremiah, 2006; Adeyemo and Soboyejo, 2006; Akigbe et al., 2009; Pennap et al., 2011). It is of specific interest to note that $\mathrm{HbSS}$ was not found in this pregnant women population. This is in line with the report of Uneke et al. (2007) who reported the absence of $\mathrm{HbSS}$ in pregnant women population in Abakaliki, Nigeria and in malaria-endemic areas of Kenyan population (Moormann et al., 2003). The decline in prevalence of $\mathrm{HbSS}$ in our study and other studies in Nigerian population (Jeremiah, 2005; Pennap et al., 2011) compared to those reported earlier (Nwafor and Banigo, 2001; Bakare et al., 2006) implies that the sickling gene pool is gradually shrinking thus lowering the occurrence of hemoglobinopathies in the Nigerian populations. This could be attributed to increased awareness of the disease, improved socio-economic conditions and other environmental and genetic factor which have an overall effect on the sickling gene pool (Jeremiah, 2006).

\section{CONCLUSION}

This study forms the basis for genetic counseling in the study population and will help prospective mothers make informed decisions before and after giving birth.

\section{AKNOWLEDGEMENT}

We wish to thank the Hospital Management of Ayetoro General Hospital, Ogun State, Nigeria for granting us access to the data used for this publication.

\section{REFERENCES}

Adeyemo, O.A. and O.B. Soboyejo, 2006. Frequency distribution of $\mathrm{ABO}, \mathrm{RH}$ blood groups and blood genotypes among the cell biology and genetics students of University of Lagos, Nigeria. Afr. J. Biotech.

Akigbe, R.E., S.F. Ige, A.O. Afolabi, O.M. Azeez and G.J. Adegunlola et al., 2009. Prevalence of haemoglobin variants, $\mathrm{ABO}$ and rhesus blood groups in ladoke akintola university of technology, ogbomosho, Nigeria. Trends Med. Res., 4: 24-29. DOI: $10.3923 / \mathrm{tmr} .2009 .24 .29$

Avent, N.D., 1998. The rhesus blood group system: Insights from recent advances in molecular biology. Transfusion Med. Rev., 13: 245-266. DOI: 10.1016/S0887-7963(99)80056-X

Bakare, A.A., M.A. Azeez and J.O. Agbolade, 2006. Gene frequencies of $\mathrm{ABO}$ and rhesus blood groups and haemoglobin variants in Ogbomoso, SouthWest Nigeria. Afr. J. Biotech., 5: 224-229.

Burrows, T.D., A. King and Y.W. Loke, 1994. Expression of adhesion molecules by endovascular trophoblast and decidual endothelial cells: Implications for vascular invasion during implantation. Placenta, 15: 21-33. DOI: 10.1016/S0143-4004(05)80233-4

Dennis, Y.M., N.M. Hylem, C. Fidler, I.L. Sargent and M.F. Murphy et al., 1998. Prenatal diagnosis of fetal $\mathrm{RhD}$ status by molecular analysis of maternal plasma. New Engl. J. Med., 337: 1734-1738. PMID: 9845707 
Erhabor, O., T.C. Adias, Z.A. Jeremiah and M.L. Hart, 2010. Abnormal hemoglobin variants, ABO and Rhesus blood group distribution among students in the Niger Delta of Nigeria. Pathol. Lab. Med. Int., 2: 41-46. DOI: 10.2147/PLMI.S9488

Greenwell, P., 1997. Blood group antigens: Molecules seeking a function? Glycoconjugate J., 14: 159-173. DOI: 10.1023/A:1018581503164

Jeremiah, Z.A. and F.I. Buseri, 2003. Rh antigen and phenotype frequencies and probable genotypes for the four main ethnic groups in Port Harcourt, Nigeria. Immunohematology, 19: 86-88. PMID: 15373686

Jeremiah, Z.A., 2005. An assessment of the clinical utility of routine antenatal screening of pregnant women at first clinic attendance for haemoglobin genotypes, haematocrit, $\mathrm{ABO}$ and rh blood groups in port harcourt, Nigeria. Afr. J. Reprod. Health, 9: 112-117.

Jeremiah, Z.A., 2006. Abnormal haemoglobin variants, $\mathrm{ABO}$ and $\mathrm{Rh}$ blood groups among student of African descent in Port Harcourt, Nigeria. Afr. Health Sci., 6: 177-181.

Jones, C.J., T.C. Santos, M. Abd-Elnaeim, V. Dantzer and M.A. Miglino, 2004. Placental glycosylation in peccary species and its relation to that of swine and dromedary. Placenta, 25: 649-657. DOI: 10.1016/j.placenta.2003.12.007

Jones, C.J.P., V. Dantzer, R. Leiser, C. Krebs and R.W. Stoddart, 1997. Localisation of glycans in the placenta: A comparative study of epitheliochorial, endotheliochorial and haemomonochorial placentation. Microsc. Res. Tech., 38: 100-114. DOI: 0029(19970701/15)38:1/2<100::AIDJEMT11>3.0.CO;2-T

Loscertales, M. and B.J. Brabin, 2006. ABO phenotypes and malaria related outcomes in mothers and babies in The Gambia: A role for histo-blood groups in placental malaria? Malaria J., 5: 72-72. DOI: $10.1186 / 1475-2875-5-72$
Moormann, A.M., P.E. Emburry, J. Opondo, O.P. Sumba and J.H. Ouma et al., 2003. Frequencies of sickle cell trait and glucose-6-phosphate dehydrogenase deficiency differ in highland and nearby lowland malaria-endemic areas of Kenya. Trans. R Soc. Trop. Med. Hyg., 97: 513-514. PMID: 15307413

Nwafor, A. and B.M. Banigo, 2001. A comparison of measured and predicted haemoglobin genotype in a Nigerian population in Bonny, Rivers State, Nigeria. J. Applied Sci. Environ. Manage., 5: 79-81.

Pennap, G.R., E. Envoh and I. Igbawua, 2011. Frequency distribution of hemoglobin variants, $\mathrm{ABO}$ and Rhesus blood groups among students of African Descent. Br. Microbiol. Res. J., 1: 33-40.

Ravn, V. and E. Dabelsteen, 2000. Tissue distribution of histo-blood group antigens. APMIS, 108: 1-28. DOI: 10.1034/j.1600-0463.2000.d01-1.x

Seeley, R.R., T.D. Stephens and P. Tate, 2008. Anatomy and Physiology. 8th Edn., The McGraw Hill, Dubuque, IA., ISBN-10: 0073293687, pp: 1116.

Skovlund, V.R., 1997. ABH and related histo-blood group antigens in normal and malignant human endometrium in relation to genetic and hormonal factors. APMIS, 69: 5-33. DOI: 10.1111/j.16000463.1997.tb05597.x

Tamarin, R.H., 2002. Principles of Genetics. 7th Edn., McGraw Hall, Boston, ISBN-10: 0072334193, pp: 609.

Thrower, S., J.N. Bulmer, N.R. Griffin and M. Wells, 1990. Further studies of lectin binding by villous and extravillous trophoblast in normal and pathological pregnancy. Int. J. Gynecol. Pathol., 10: 238-251. DOI: 10.1097/00004347-19910700000003

Uneke, C.J., I. Sunday-Adeoye, F.E. Iyare, E.I. Ugwuja and D.D. Duhlinska, 2007. Impact of maternal Plasmodium falciparum malaria and haematological parameters on pregnancy and its outcome in southeastern Nigeria. J. Vector Borne Dis., 44: 285 290. PMID: 18092538 